\title{
Productivity of hybrids of corn depending on growth-promoting factors and micro-fertilizers in conditions of irrigation
}

\author{
R. Vozhegova, \\ doctor of agricultural sciences \\ Yu. Lavrinenko, \\ Corresponding Member of the National Academy of Sciences of Ukraine, Doctor of Agricultural \\ Sciences \\ O. Gozh \\ Institute of irrigated agriculture of NAAS of Ukraine
}

The purpose. To determine effective growth-promoting factors and micro-fertilizers in view of biological features of new hybrids of corn of different groups of maturity in conditions of irrigation of South Steppe of Ukraine and their effect on formation of grain productivity of plants. Methods. Field (for scoping yield and measuring biometrical indexes); laboratory (moisture test of soil, moisture content in grain and quality factors of grain); statistical (assessment of reliability of the gained results); calculated (for economic and energy assessments of used methods of growing). Results. Efficiency of application of micro-fertilizers and growthpromoting factors in sowings of hybrids of corn of different groups of maturity in conditions of irrigation is fixed. The most sensitive to application of micro-fertilizers and growth-promoting factors in conditions of irrigation were middle-ripening and middle-late hybrids. Conclusions. In conditions of irrigation on darkchestnut soils of the south of Ukraine for deriving productivity of grain of corn in the range of $10-14$ t/hectare it is necessary to apply efficient innovative growth-promoting factors and micro-fertilizers and it is expedient to grow new hybrids of corn of intensive type of middle-ripening and middle-late groups Zbruch, Kahovsky, DN Hetera, Arabat, etc.

Key words: corn, hybrids, growth-promoting factors, micro-fertilizers, irrigation, productivity.

Introduction. Corn is one of the most productive cereal crops of universal purpose, which is rich in crops with a high level of crop yields. However, it is characterized by a fairly high drought tolerance, and optimization of the main agrotechnical measures can form a constant performance and without watering. The most effective factors influencing the grain yield of corn are the hybrid composition, application of irrigation, mineral fertilizers, microfertilizers and growth stimulants [1-3]. Due to the need to improve the technological methods of cultivating maize hybrids and to determine the adaptability of certain genotypes to soil-ecological and technological conditions of cultivation in the south of Ukraine, a study was conducted with eight new domestic hybrids of corn under irrigation conditions. During the growing hybrids, microfertilizers and growth promoters have been introduced during irrigation to the experimental scheme, as it is known that their application is one of the most important ways to increase yield by $15-20 \%$ and improve product quality [4-6]. The purpose of the work is to identify effective microfertilizers and growth promoters taking into account the biological characteristics of new hybrids of maize of different FAO groups in irrigated conditions in the south of Ukraine and to trace their influence on the formation of grain productivity of plants.

Materials and methods. The following methods were used: field - for analysis of the interaction of the object of study with the investigated factors and the natural environment in conjunction with the crop and biometric measurements; laboratory - to determine soil moisture content, moisture content in grain, grain quality indices; statistical - to determine the reliability of the results; Estimated - for economic and energy assessment of the investigated methods of cultivation.

Results and discussion. The research was conducted during 2013-2015 at the experimental field of the Institute of Irrigated Agriculture of the National Academy of Sciences, located in the south of Ukraine in the zone of the Ingulets Irrigated Array. The soil of the experimental area is dark chestnut, medium-loam, weakly solonchitous at a deep level of groundwater.

Experiment two-factor: factor A - different maize hybrids in different FAO groups (DN Pivicha, Tendra, Baturin 287 MW, Skadovsky, Zbruch, Kakhovsky, DN Hetera, Arabat); Factor B - microfertilizers and growth stimulants (without processing; Sizam-Nano - seed treatment; Sizam-Nano - seed treatment + Foliar spraying of HUMIN PLUS in 7-8 leaves; Sizam-Nano - seed treatment + Foliar spraying in the 7-8 phase 
leaves of Grainaktiv-S; HUMIN PLUS - seed treatment + foliar spraying in the 7-8-leaf phase; Nanomix seed treatment + foliar spraying in the 7-8 leaf phase).

Four-time repetition with placement of variants by randomized split plot method. The area of sown areas was $70 \mathrm{~m}^{2}$, accounting - $50 \mathrm{~m}^{2}$. The above-mentioned hybrids of corn were grown on grain.

Agricultural machinery cultivation of corn in experiments is generally accepted for the southern region of Ukraine, besides the investigated factors.

Predecessor is soy. Pouring was carried out in a way of raining. According to the experimental scheme, before sowing, the seeds were treated with solutions of specimen, and then in the vegetation period in the 78-leaf phase, spraying was carried out. Laying and performing experiments, selection of soil and plant samples, preparation of them for analysis were carried out in accordance with the methodology of the experimental case [7].

Corn belongs to drought resistant crops (mesophytes). However, the soil moisture shortage is a serious limiting factor in obtaining high levels of grain yield. Extreme weather conditions, which are often observed in the Southern Steppe of Ukraine (dry weather, high temperature, lack of productive moisture), negatively affect not only the growth and development of plants of this culture, but also reduce the effectiveness of fertilizers.

In our experiments, corn crops were wetted, using vegetative soils at pre-loading soil moisture of $75 \%$ of the lowest moisture content (HB) in a layer of $0-70 \mathrm{~cm}$. The efficiency of the implementation of energy and resource-saving technologies in the agro-industrial sector depends to a large extent on such an important factor as microfertilizers and growth stimulators of plants containing important trace elements, phytohormones and growth promoters. Their use reduces the use of chemical preparations, in particular, plant protection products, improves the efficiency of a number of technological operations, increases the resistance of plants to adverse environmental factors and the action of pathogens, improves not only quantitative but also qualitative characteristics of products [8].

Application of microfertilizers and plant growth stimulants for the period of 2013-2015 on maize crops positively influenced the growth and development of plants and, consequently, the formation of a crop. Thus, over the years of research, regardless of the timing of obtaining hybrids, microfertilizers and growth stimulants have, on average, increased the yield of corn hybrids at 0.38-1.26 t / ha with a yield increase of $3.80-10.04 \%$ (table 1, 2 ) This is due to the full or partial provision of plants with the necessary trace elements and growth-stimulating substances with their distribution during the growing of culture, especially during critical periods of plant development. The yield of corn grain under irrigation without treatment with drugs for all groups of hybrid hybrids fluctuated on average for 2013-2015 within the range of 9.57-12.54 $\mathrm{t} /$ ha. The highest yield $(13,80 \mathrm{t} / \mathrm{ha})$ over the years of irrigation research has generated the medium-late hybrid Arabate with the integrated application of growth stimulants - seed treatment of Sizam-Nano and corn plant nutrition in the 7-8 leaf of Grainaktiv-C, which is $1.26 \mathrm{t} /$ ha more than control.

A similar pattern is found for other hybrids. The yield increase due to such processing on average by hybrids was $0.94-1.26 \mathrm{t} /$ ha.

It should be noted that the most sensitive reaction to the use of microfertilizers and growth stimulants under irrigation conditions was found in the middle and late hybrids.

Table 1. The yield of maize hybrids FAO $\mathbf{1 8 0 - 2 9 0}$ grains depending on microfertilizers and growth stimulants, $\mathrm{t} / \mathrm{ha}$

\begin{tabular}{|l|l|l|l|l|l|}
\hline Hybrid (A) & Cultivation by specimen (B) & $2013 \mathrm{p}$. & $2014 \mathrm{p}$. & $2015 \mathrm{p}$. & average \\
\hline \multirow{4}{*}{$\begin{array}{l}\text { DN Pivicha (FAO } \\
180)\end{array}$} & 1. Uncultivated & 10,28 & 9,98 & 9,68 & 9,98 \\
\cline { 2 - 6 } & 2. Sizam-Nano & 10,96 & 10,68 & 10,31 & 10,65 \\
\cline { 2 - 6 } & $\begin{array}{l}\text { 3. Sizam-Nano + } \\
\text { HUMIN PLUS }\end{array}$ & 10,98 & 10,76 & 10,33 & 10,69 \\
\cline { 2 - 6 } & 4. Sizam-Nano + Grainaktiv-C & 11,18 & 10,98 & 10,51 & 10,89 \\
\cline { 2 - 6 } & 5. HUMIN PLUS & 10,82 & 10,74 & 10,27 & 10,61 \\
\cline { 2 - 6 } & 6. Nanomix & 11,11 & 10,93 & 10,39 & 10,81 \\
\hline \multirow{3}{*}{ Tendra (FAO 190) } & 1. Uncultivated & 9,91 & 9,57 & 9,23 & 9,57 \\
\cline { 2 - 6 } & 2. Sizam-Nano & 10,52 & 10,22 & 9,71 & 10,15 \\
\cline { 2 - 6 } & 3. Sizam-Nano + & 10,59 & 10,27 & 9,77 & 10,21 \\
\hline
\end{tabular}




\begin{tabular}{|c|c|c|c|c|c|}
\hline & HUMIN PLUS & & & & \\
\hline & 4. Sizam-Nano + Grainaktiv-C & 10,89 & 10,47 & 9,96 & 10,44 \\
\hline & 5. HUMIN PLUS & 10,47 & 10,19 & 9,67 & 10,11 \\
\hline & 6. Nanomix & 10,81 & 10,47 & 9,86 & 10,38 \\
\hline \multirow{6}{*}{$\begin{array}{l}\text { Baturin } \\
287 \mathrm{MB} \\
(\text { FAO 240) }\end{array}$} & 1. Uncultivated & 10,45 & 10,25 & 10,05 & 10,25 \\
\hline & 2. Sizam-Nano & 11,14 & 10,96 & 10,60 & 10,90 \\
\hline & $\begin{array}{l}\text { 3. Sizam-Nano + } \\
\text { HUMIN PLUS }\end{array}$ & 11,25 & 11,01 & 10,65 & 10,97 \\
\hline & 4. Sizam-Nano + Grainaktiv-C & 11,51 & 11,17 & 10,95 & 11,21 \\
\hline & 5. HUMIN PLUS & 11,15 & 10,81 & 10,50 & 10,82 \\
\hline & 6. Nanomix & 11,43 & 11,07 & 10,80 & 11,10 \\
\hline \multirow{6}{*}{$\begin{array}{l}\text { Skadovsky } \\
\text { 290) }\end{array}$} & 1. Uncultivated & 10,88 & 10,56 & 10,30 & 10,58 \\
\hline & 2. Sizam-Nano & 11,55 & 11,33 & 10,93 & 11,27 \\
\hline & $\begin{array}{l}\text { 3. Sizam-Nano + } \\
\text { HUMIN PLUS }\end{array}$ & 11,68 & 11,40 & 10,97 & 11,35 \\
\hline & 4. Sizam-Nano + Grainaktiv-C & 11,87 & 11,63 & 11,21 & 11,57 \\
\hline & 5. HUMIN PLUS & 11,59 & 11,35 & 10,90 & 11,28 \\
\hline & 6. Nanomix & 11,80 & 11,58 & 11,09 & 11,49 \\
\hline \multirow{2}{*}{$\mathrm{HIP}_{05}$, т/га } & $\mathbf{A}=$ & 0,33 & 0,41 & 0,37 & \\
\hline & $\mathrm{B}=$ & 0,18 & 0,24 & 0,22 & \\
\hline
\end{tabular}

Table 2. The yield of maize hybrids FAO 310-430 grains depending on microfertilizers and growth stimulants, $t /$ ha

\begin{tabular}{|c|c|c|c|c|c|}
\hline Hybrid (A) & Cultivation by specimen (B) & $2013 p$. & $2014 \mathrm{p}$. & $2015 p$. & average \\
\hline \multirow{6}{*}{$\begin{array}{l}\text { Zbruch } \\
\text { (FAO 310) }\end{array}$} & 1. Uncultivated & 11,32 & 11,10 & 10,82 & 11,08 \\
\hline & 2. Sizam-Nano & 12,09 & 11,85 & 11,37 & 11,77 \\
\hline & $\begin{array}{l}\text { 3. Sizam-Nano + } \\
\text { HUMIN PLUS }\end{array}$ & 12,11 & 11,93 & 11,45 & 11,83 \\
\hline & 4. Sizam-Nano + Grainaktiv-C & 12,60 & 12,32 & 11,68 & 12,20 \\
\hline & 5. HUMIN PLUS & 12,03 & 11,77 & 11,36 & 11,72 \\
\hline & 6. Nanomix & 12,50 & 12,16 & 11,49 & 12,05 \\
\hline \multirow{6}{*}{$\begin{array}{l}\text { Kakhovsky (FAO } \\
380)\end{array}$} & 1. Uncultivated & 11,61 & 11,29 & 11,06 & 11,32 \\
\hline & 2. Sizam-Nano & 12,36 & 12,12 & 11,61 & 12,03 \\
\hline & $\begin{array}{l}\text { 3. Sizam-Nano + } \\
\text { HUMIN PLUS }\end{array}$ & 12,40 & 12,16 & 11,68 & 12,08 \\
\hline & 4. Sizam-Nano + Grainaktiv-C & 12,86 & 12,60 & 11,95 & 12,47 \\
\hline & 5. HUMIN PLUS & 12,26 & 12,00 & 11,50 & 11,92 \\
\hline & 6. Nanomix & 12,78 & 12,42 & 11,79 & 12,33 \\
\hline \multirow{6}{*}{$\begin{array}{l}\text { DN Hetera (FAO } \\
420)\end{array}$} & 1. Uncultivated & 12,21 & 11,95 & 11,66 & 11,94 \\
\hline & 2. Sizam-Nano & 13,08 & 12,80 & 12,28 & 12,72 \\
\hline & $\begin{array}{l}3 \text { Sizam-Nano + } \\
\text { HUMIN PLUS }\end{array}$ & 13,12 & 12,86 & 12,36 & 12,78 \\
\hline & 4. Sizam-Nano + Grainaktiv-C & 13,52 & 13,24 & 12,69 & 13,15 \\
\hline & 5. HUMIN PLUS & 12,98 & 12,72 & 12,07 & 12,59 \\
\hline & 6. Nanomix & 13,44 & 13,16 & 12,46 & 13,02 \\
\hline \multirow{5}{*}{ Arabate (FAO 430) } & 1. Uncultivated & 12,74 & 12,52 & 12,36 & 12,54 \\
\hline & 2. Sizam-Nano & 13,67 & 13,41 & 13,06 & 13,38 \\
\hline & $\begin{array}{l}\text { 3. Sizam-Nano + } \\
\text { HUMIN PLUS }\end{array}$ & 13,69 & 13,49 & 13,11 & 13,43 \\
\hline & 4. Sizam-Nano + Grainaktiv-C & 14,17 & 13,83 & 13,40 & 13,80 \\
\hline & 5. HUMIN PLUS & 13,51 & 13,27 & 12,88 & 13,22 \\
\hline
\end{tabular}




\begin{tabular}{|l|l|l|l|l|l|}
\hline & 6. Nanomix & 14,10 & 13,72 & 13,31 & 13,71 \\
\hline \multirow{2}{*}{$\mathrm{HIP}_{05}, \mathrm{~T} / \mathrm{ra}$} & $\mathbf{A}=$ & 0,33 & 0,41 & 0,37 & \\
\cline { 2 - 5 } & $\mathrm{B}=$ & 0,18 & 0,24 & 0,22 & \\
\hline
\end{tabular}

According to research results of 2013-2015, it has been established that greater stability of yield (both actual and potential) under irrigation conditions was demonstrated by hybrids of middle and middle-aged groups.

The yield loss rate, depending on the biotype, was the minimum in the studied hybrids FAO 310-430, which indicates some advantages in the stability of high yields of medium and late hybrids over high-speed hybrids of corn under irrigation conditions.

The economic efficiency of the technology elements, for example, hybrids of different groups of maturation, micronutrient fertilizers and growth stimulators, along with the use of standard costs of material and technical resources for growing corn on grain during irrigation, is determined for the objective justification of the most rigorous combination of investigated agro-measures.

General standards of production, prices for manual and mechanized work were taken in accordance with the recommended standards for production [9].

In determining the value of gross output from 1 hectare in the calculations used the main type of product grain. As a result, it was established that the cost of the obtained products in the cultivation of maize varies with the same regularity as the yield of the crop (table 3 ).

When calculating economic efficiency it was found that for growing of the studied hybrids without the use of growth stimulators and microfertilizers, the production costs were by $0,8-1,7 \%$ less than the inclusion of the indicated factor in the technological methods of cultivation of corn.

The maximum (21575-21741 UAH / ha) they are determined when applying the drug "HUMIN PLUS" in the middle and late hybrids.

The highest net profit in the experiment, regardless of growth stimulators and microfertilizers, provided the medium-late Hybrid Arabate. It was the highest in hybrids under conditions of use of growth stimulants "Sizam-Nano" and "Grainaktiv-S" (table 3).

Growth stimulators and micronutrient compared to unprocessed variants increased net profits on average by hybrids by $1.7-12.2 \%$.

Table 3. The economic efficiency of growing hybrids of corn FAO 180-430 depending on microfertilizers and growth stimulants for 2015

\begin{tabular}{|c|c|c|c|c|c|}
\hline $\begin{array}{l}\text { Maturity group of } \\
\text { hybrids (A) }\end{array}$ & $\begin{array}{ll}\text { Cultivation } & \text { by } \\
\text { specimen (B) }\end{array}$ & Yield, t/ha & $\begin{array}{l}\text { Product value, } \\
\text { UAN/ha }\end{array}$ & $\begin{array}{l}\text { Net profit, } \\
\text { UAN/ha }\end{array}$ & Profitability, \% \\
\hline \multirow{6}{*}{$\begin{array}{l}\text { FAO } \\
180-190\end{array}$} & 1. Uncultivated & 9,23 & 27690 & 7042 & 34,1 \\
\hline & 2. Sizam-Nano & 9,71 & 29130 & 8297 & 39,8 \\
\hline & $\begin{array}{l}\text { 3. Sizam-Nano + } \\
\text { HUMIN PLUS }\end{array}$ & 9,77 & 29310 & 8415 & 40,3 \\
\hline & $\begin{array}{l}\text { 4. Sizam-Nano + } \\
\text { Grainaktiv-C }\end{array}$ & 9,96 & 29880 & 8961 & 42,8 \\
\hline & 5. HUMIN PLUS & 9,67 & 29010 & 8199 & 39,4 \\
\hline & 6. Nanomix & 9,86 & 29580 & 8692 & 41,6 \\
\hline \multirow{6}{*}{$\begin{array}{l}\text { FAO } \\
240-290\end{array}$} & 1. Uncultivated & 10,45 & 31350 & 10638 & 51,4 \\
\hline & 2. Sizam-Nano & 11,14 & 33420 & 12523 & 59,9 \\
\hline & $\begin{array}{l}\text { 3. Sizam-Nano + } \\
\text { HUMIN PLUS }\end{array}$ & 11,25 & 33750 & 12791 & 61,0 \\
\hline & $\begin{array}{l}\text { 4. Sizam-Nano + } \\
\text { Grainaktiv-C }\end{array}$ & 11,51 & 34530 & 13547 & 64,6 \\
\hline & 5. HUMIN PLUS & 11,15 & 33450 & 12575 & 60,2 \\
\hline & 6. Nanomix & 11,43 & 34290 & 13338 & 63,7 \\
\hline \multirow{3}{*}{$\begin{array}{l}\text { FAO } \\
310-380\end{array}$} & 1. Uncultivated & 11,32 & 33960 & 12548 & 58,6 \\
\hline & 2. Sizam-Nano & 12,09 & 36270 & 14673 & 67,9 \\
\hline & $\begin{array}{l}\text { 3. Sizam-Nano + } \\
\text { HUMIN PLUS }\end{array}$ & 12,11 & 36330 & 14671 & 67,7 \\
\hline
\end{tabular}




\begin{tabular}{|c|c|c|c|c|c|}
\hline & $\begin{array}{l}\text { 4. Sizam-Nano + } \\
\text { Grainaktiv-C }\end{array}$ & 12,60 & 37800 & 16017 & 73,5 \\
\hline & 5. HUMIN PLUS & 12,03 & 36090 & 14515 & 67,3 \\
\hline & 6. Nanomix & 12,50 & 37500 & 15848 & 73,2 \\
\hline & 1. Uncultivated & 12,36 & 37080 & 15502 & 71,8 \\
\hline & 2. Sizam-Nano & 13,06 & 39180 & 17417 & 80,0 \\
\hline FAO & $\begin{array}{l}\text { 3. Sizam-Nano + } \\
\text { HUMIN PLUS }\end{array}$ & 13,11 & 39330 & 17505 & 80,2 \\
\hline $400-430$ & $\begin{array}{l}\text { 4. Sizam-Nano + } \\
\text { Grainaktiv-C }\end{array}$ & 13,40 & 40200 & 18351 & 84,0 \\
\hline & 5. HUMIN PLUS & 12,88 & 38640 & 16899 & 77,7 \\
\hline & 6. Nanomix & 13,31 & 39930 & 18112 & 83,0 \\
\hline
\end{tabular}

In 2015 the highest level of profit (18,351 UAH / ha) p htynf, tkmyscn. 84\% was obtained on Arabat hybrid seeds under seed treatment with Sizam-Nano growth stimulator and in Grain-Active-C phase 7-8 leaves, which is $12.2 \%$ higher than unprocessed variants. High profits were provided by hybrids of DN Hetera and Kakhovsky.

A completely different situation has arisen in determining the profitability of cultivating maize hybrids. Without the use of growth stimulators and microfertilizers in 2015 for all hybrids it was within the range of $34.1-71.8 \%$.

In terms of drug treatment, the level of profitability increased and averaged $35.9-84.0 \%$ in terms of treatments. It should be noted that he was much higher than growing hybrids of corn with a longer period of vegetation, and the cost of growing the unit of production with it, on the contrary, declined.

\section{Conclusion}

In the conditions of irrigation on the dark chestnut soils of southern Ukraine, for yield of corn grain at the level of 10-14 $\mathrm{t} /$ ha it is necessary to apply innovative growth stimulators and microfertilizers. In this case it is expedient to grow hybrids of corn of middle-aged and middle-aged groups - Zbruch, Kakhovsky, DN Hetera, Arabat.

\section{Bibliography}

1. Stratehichni napryamy rozvytku sil's'koho hospodarstva Ukrayiny na period do 2020 roku; za red. Yu.O. Lupenka, V.Ya. Mesel'-Veselyaka. - K.: NNTs «IAE», 2012. - $182 \mathrm{s.}$

2. Troyer A.F. Background of U. S. hybrid corn: II. Breeding, climate, and food. Crop Sci. — 2004. — № 44(2). - R. 370-380.

3. Kukurudza na zroshuvanykh zemlyakh pivdnya Ukrayiny: monohrafiya/Yu.O. Lavrynenko, S.V. Ko-ko-vikhin, P.V. Pysarenko ta in.; za red. Yu.O. Lavrynenka. — Kherson: Aylant, 2009. - 428 s.

4. Kvitka H. Kukurudza - «za» yevrointehratsiyu!/H. Kvit-ka//Propozytsiya. — 2013. — № 12 (222). S. 38-40.

5. Lykhochvor V. V. Roslynnytstvo. Suchasni intensyvni tekhnolohiyi vyroshchuvannya osnovnykh pol'ovykh kul'tur/V.V. Lykhochvor, V.F. Petrychenko. - L'viv: NVF «Ukrayins'ki tekhnolohiyi», 2006. - S. 271-326.

6. Dospekhov B.A. Metodyka polevoho opyta (s osnovamy statystycheskoy obrabotky rezul'tatov yssledovanyy) [5-e yzd., dop. y pererab.]/B.A. Do-spekhov. - M.: Ahropromyzdat, 1985. - $351 \mathrm{~s}$.

7. Mikel M.A. Genetic Composition of Contemporary U.S. commercial dent corn germplasm/M.A. Mikel//Crop Scien-ce. — 2011. — № 51(2). - R. 592-599.

8. Rudyshyn S.D. Osnovy biotekhnolohiyi roslyn/S.D. Rudyshyn. - Vinnytsya, 1998. - S. 22-37.

9. Malakouti M.J. The effect of micronutrients in ensuring efficient use of macronutrients/M.J. Malakouti//Turk J Agric For. 2008. — № 32(3). - R. 215-220.

10. Rasheed M. Impact of nitrogen and sulfur ap-plication on growth and yield of maize (Zea mays L.) crop/M. Rasheed, H. Ali, T. Mahmood//J. Res Sci. — 2004. — № 15(2). — R. 153-157.

11. Shcherbakov V.Ya. Maybutnye za suspenziyeyu/V.Ya. Shcherbakov, Yu.M. Hobelyak//Propozytsiya. — 2011. — № 2 (188). - S. 2-3. 